\title{
Nilai Perusahaan Sektor Farmasi Yang terdaftar Di Bursa Efek Indonesia (BEI) Di Tinjau Dari Beberapa Faktor
}

\author{
Yuniep Mujati Suaidah \\ Program Study Akuntansi, STIE PGRI Dewantara Jombang \\ Jawa Timur, Indonesia \\ Email: yunip.dewantara@gmail.com
}

\begin{abstract}
ABSTRAK
Nilai perusahaan merupakan cerminan bagaimana keadaan perusahaan yang diharapkan investor dapat memberikan keuntungan sehingga perlu untuk ditinjau apakah ada pengaruh GCG, CSR, intellectual capital dan kinerja keuangan terhadap nilai perusahaan. Penelitian ini menggunakan data sekunder dengan pengumpulan data melalui dokumentasi. Data laporan keuangan perusahaan Farmasi yang terdaftar di PT. Bursa Efek Indonesia tahun 2014-2018, tercatat sebanyak 9 perusahaan dengan total 45 laporan keuangan yang digunakan sebagai sampel penelitian dengan teknik purposive sampling sebagai pengambilan sampel. Analisis data dengan menggunakan analisis regresi linier berganda. Hasil penelitian dapat disimpulkan terdapat pengaruh positif signifikan GCG terhadap nilai perusahaan. Terdapat pengaruh positif signifikan CSR terhadap nilai perusahaan. Tidak terdapat pengaruh intellectual capital terhadap nilai perusahaan. Terdapat pengaruh positif signifikan kinerja keuangan terhadap nilai perusahaan.
\end{abstract}

Kata Kunci : GCG, CSR, intellectual capital, kinerja keuangan, nilai perusahaan

\section{PENDAHULUAN}

Nilai perusahaan adalah hal utama yang dilihat sebelum investor memutuskan untuk menginvestasikan dana di suatu indutri. Kenaikan nilai perusahaan dari tahun ke tahun adalah suatu cerminan keberhasilan perusahaan dalam melaksanakan usahanya. Nilai perusahaan sangat berarti sebab dengan nilai perusahaan yang tinggi akan diiringi dengan tingginya kemakmuran pemegang saham (Brigham dan Gapenski,1996). Husnan (1996) menjelaskan bahwa nilai perusahaan adalah harga yang akan dibayar oleh calon pembeli apabila perusahaan tersebut dijual. Mengoptimalkan nilai perusahaan sangat berguna bagi suatu perusahaan, sebab dengan mengoptimalkan nilai perusahaan berarti pula mengoptimalkan kemakmuran pemegang saham dimana bagian dari tujuan utama perusahaan (Salvatore, 2005). Berdasarkan pendapat tersebut, maka nilai perusahaan merupakan suatu alat pertimbangan utama sebelum melakukan investasi ataupun membeli perusahaan.

Pada tahun2016 Ketua Ikatan Apoteker Indonesia Daerah Istimewa Yogyakarta (IAI DIY), menyatakan bahwa Badan Penyelenggara Jaminan Sosial (BPJS) Kesehatan memanglah diharapkan bisa menekan biaya pengobatan. Salah satunya dengan memberikan rekomendasi penggunaan obat generik. Memang pada 
akhirnya memberiakn dampak pada penurunan pendapatan perusahaan sektor farmasi, tetapi hal ini demi keterjangkauan obat yang digunakan masyarakat. Pasar farmasi Indonesia tahun 2016 diperkirakan berkembang 11,8 persen dengan total nilai sebesar USD 4,6 Miliar dengan konsumsi per kapita USD 19. Akan tetapi bagi perusahaan sektor farmasi, perkembangan hanya dinikmati oleh perusahaan sektor farmasi yang besar, sebaliknya perusahaan dalam negeri dengan skala kecil menghadapi kesulitan dalam memasarkan produknya (Amr, 2016).

Untuk memaksimalkan nilai perushaan maka perlu system mekanisme pengawasan dimana yang disebut Good Corporate Governance (GCG). Good corporate governance mengendalikan hubungan antara pengurus perusahaan, pemegang saham, pihak kreditur, pemerintahan, karyawan, serta pemegang kepentingan internal dan eksternal yang berkaitan dengan hak-hak serta kewajiban perusahaan sehingga GCG merupakan suatu perangkat yang mengarahkan dan mengendalikan suatu perusahaan (Cadbury Committee of United Kingdom, 1922).

Salah satu proksi dalam GCG adalah komite audit dimana komite audit bertugas untuk melaksanakan pengawan internal, serta perantara antara pemegang saham dan dewan komisaris dengan pengendalian operasional yang dilakukan oleh manajemen dan auditor baik internal maupun eksternal. Prinsip dari tugas komite audit adalah memaksimalkan pengawasan agar terhindar dari ketidaksesuaian informasi yang dapat merugikan perusahaan sehingga dapat berdampak pada penurunan nilai perusahaan (Widyaningsih, 2018).

Coorporate Social Responbility (CSR) merupakan suatu kegiatan yang sangat penting dalam membantu meningkatkan nilai perusahaa, dimana CSR merupakan suatu kegiatan yang mencerminkan tanggung jawab terkait masalah social dan lingkungan akibat dari operasional yang dilakukan oleh perusahaan. Heinkel et al. (2001) menjelaskan bahwa perusahaan perlu berasumsi bahwa salah satu strategi jangka panjang yang menguntungkan bukan merugikan perusahaan dapat melalui kegiatan CSR. Chariri (2008) menambahkan bahwa kegiatan CSR dapat menjadi alat manajerial perusahaan untuk mengurangi masalah social dan lingkungan.

Ghoul et al., 2011 dalam penelitiannya menjelaskan bahwa nilai perusahaan akan semakin meningkat jika perusahaan melakukan banyak kegiatan CSR, hal ini terjadi karena jika perusahaan banyak melakukan kegiatan CSR maka pasar akan memberikan respon positif kepada perusahaan sehingga nilai harga saham perusahaan akan meningkat. Investor akan mendukung kegiatan CSR dengan melihat bahwa kegiatan CSR mencerminkan potensi yang berkelanjutan bagi perusahaan. Karena itu banyak investor yang memperhatikan kegiatan CSR yang ditunjukkan perusahaan sebelum mengambil keputusan investasi.

Selain GCG dan CSR, nilai perusahaan dapat meningkat dengan adanya intellectual capital. Intellectual capital adalah asset tidak berwujud yang penting bagi perusahaan dimana memiliki nilai yang tinggi karena dengan adanya pelaporan intellectual capital dapat meningkatkan kinerja dan nilai perusahaan. Dimana 
pelaporan intellectual capital pada annual report dapat memberikan informasi yang menguntungkan bagi investor untuk mengambil keputusan (Rivandi, 2018).

Randa \& Solon (2012) yang didukung oleh penelitian Mohsen et al,. (2014) menjelaskan bahwa intellectual capital berpengaruh terhadap nilai perusahaan yang diukur dengan model Pulic. Firer dan Williams (2003) menambahkan bahwa perusahaan dengan tingkat investasi yang tinggi dan intellectual capital yang besar maka investor akan menilai perusahaan lebih tinggi dan meningkatkan investsi investor pada perusahaan tersebut karena investor memandang bahwa intellectual capital merupakan sumber dari kekuatan perusahaan untuk bersaing mencapai keunggulan yang kompetitif.

Kondisi baik buruknya suatu perusahaan dapat dilihat dari kineja keuangan perusahaan salah satunya dengan profitabilitas. Miller and Modigliani (1961) menjelaskan bahwa nilai perusahaan dapat meningkat salah satunya dengan earnings power dari asset perusahaan, dimana semakin tinggi earnings power maka semakin efisien perputaran aset dan atau semakin tinggi profit margin yang diperoleh perusahaan sehingga nilai perusahaan akan meningkat.

Berdasarkan latar belakang tersebut maka penelitian ini bertujuan untuk mengetahui pengaruh GCG yang di ukur dengan komite audit, CSR, intellectual capital dan kinerja keuangan yang diukur dengan ROA terhadap nilai perusahaan perusahaan sektor Farmasi yang terdaftar di Bursa Efek Indonesia.

\section{METODE PENELITIAN}

Penelitian ini merupakan penelitian deskriptif kuantitatif. Metode pengumpulan data melalui dokumentasi. Teknik pengambilan sampel dengan purposive sampling. Analisis data untuk pengujian hipotesis pada penelitian ini menggunakan analisis regresi linier berganda.

Asumsi Klasik

ANALISIS DATA

Uji Normalitas

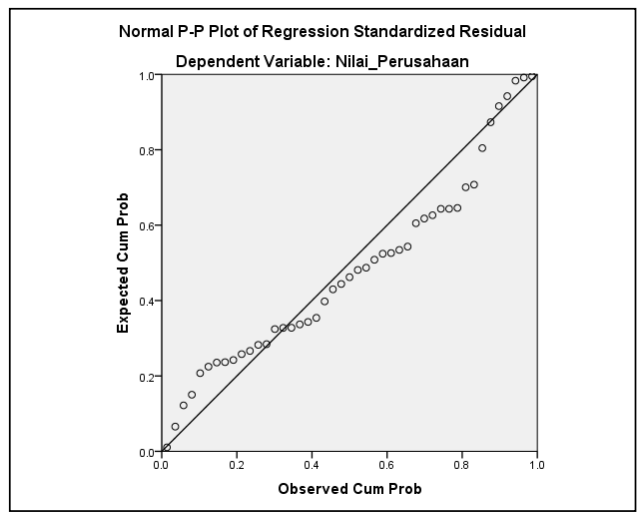

Gambar 1. Uji Normalitas 
Berdasarkan gambar 2. Normal Probability Plot menunjukkan bahwa data menyebar di sekitar garis diagonal dan penyebaran data searah mengikuti garis diagonal sehingga dapat dikatakan data berdistribusi normal.

\section{Uji Heteroskedastisitas}

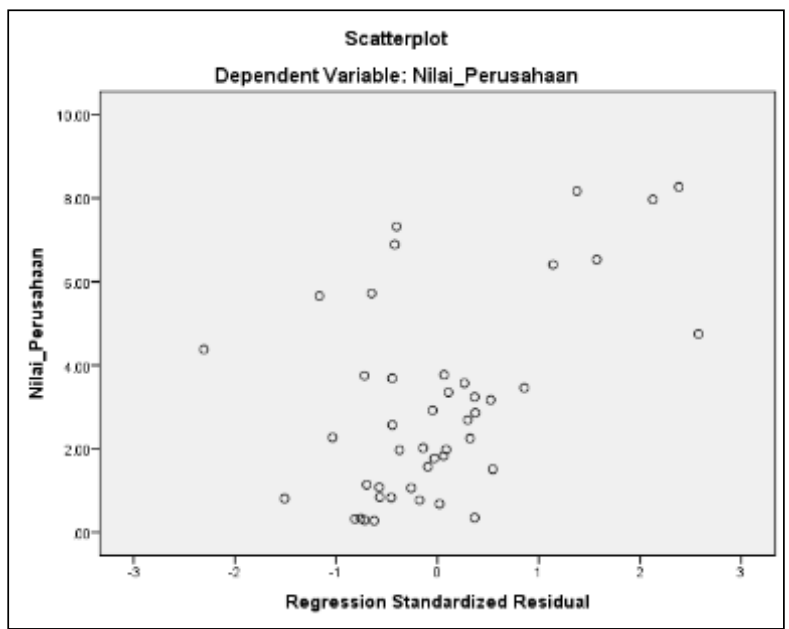

Gambar 2.Uji Heteroskedastisitas

Berdasarkan gambar 3. menunjukkan bahwa tidak terjadi heterokedastisitas karena data tersebar secara acak di atas maupun di bawah angka 0 pada sumbu Y serta tidak terdapat pola yang jelas

\section{Uji Multikolineritas}

Tabel 1. Uji Multikolineritas

\begin{tabular}{|l|r|r|}
\hline \multicolumn{1}{|c|}{ Variabel } & \multicolumn{2}{c|}{$\begin{array}{l}\text { Collinearity } \\
\text { Statistics }\end{array}$} \\
\cline { 2 - 3 } & Tolerance & \multicolumn{1}{c|}{ VIF } \\
\hline GCG & 0.888 & 1.127 \\
\hline CSR & 0.894 & 1.119 \\
\hline Intellectual capital & 0.800 & 1.250 \\
\hline Kinerja keuangan & 0.837 & 1.194 \\
\hline
\end{tabular}

Berdasarkan tabel 1 menunjukkan bahwa tidak terjadi korelasi antar variabel bebas sehingga tidak terdapat gejala multikolinieritas antar variabel bebas karena nilai VIF semua variabel bebas dalam penelitian ini lebih kecil dari 10 sedangkan nilai toleransi semua variabel bebas lebih dari $10 \%$ atau 0,10 .

\section{Uji Autokorelasi}

Pada penelitian ini sampel yang diuji sebanyak $n=45, k$ (jumlah variabel independen) $=4$, sehingga diperoleh nilai $\mathrm{dL}=1,335$ dan $\mathrm{dU}=1,720$. (lampiran tabel Durbin- 
Watson). Berdasarkan hasil olah data pada tabel Model Summary dapat dilihat nilai Durbin Watson sebesar 1,778. hal ini menunjukkan bahwa nilai durbin watson diatas nilai du dan kurang dari nilai 4-du, du $<$ dw $<4$-du $(1,720<1,778<2,280)$ dan dinyatakan tidak ada autokorelasi.

\section{Persamaan Regresi}

Hasil pengujian persamaan regresi tersebut dapat dijelaskan sebagai berikut:

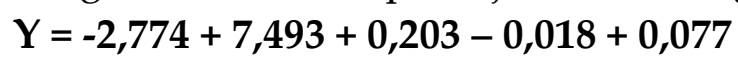

Persamaan regresi tersebut memiliki makna:

1. Nilai konstanta adalah sebesar $-2,774$ artinya jika semua variabel independen dianggap konstan 0 (nol) maka nilai perusahaan adalah sebesar -2,774.

2. GCG yang diukur dengan komite audit mempunyai koefisien regresi dengan arah positif sebesar 7,493. Jika diasumsikan variabel independen lain konstan, hal ini berarti setiap peningkatan GCG sebesar 1 persen maka nilai perusahaan akan mengalami peningkatan sebesar 7,493.

3. CSR mempunyai koefisien regresi dengan arah positif sebesar 0,203. Jika diasumsikan variabel independen lain konstan, hal ini berarti setiap peningkatan CSR sebesar 1 persen maka nilai perusahaan akan mengalami peningkatan sebesar 0,203.

4. Intellectual capital mempunyai koefisien regresi dengan arah negatif sebesar 0,018. Jika diasumsikan variabel independen lain konstan, hal ini berarti setiap penurunan intellectual capital sebesar 1 persen maka nilai perusahaan akan mengalami peningkatan sebesar 0,018.

5. Kinerja keuangan mempunyai koefisien regresi dengan arah positif sebesar 0,077. Jika diasumsikan variabel independen lain konstan, hal ini berarti setiap peningkatan kinerja keuangan sebesar 1 persen maka nilai perusahaan akan mengalami peningkatan sebesar 0,077 .

\section{Koefisien Determinasi $\left(R^{2}\right)$}

Hasil nilai R-Square pada tabel Model Summary ${ }^{\mathrm{b}}$ sebesar 0,755. Hal ini berarti bahwa $75,5 \%$ variabel dependen yaitu nilai perusahaan dapat dijelaskan oleh variabel independen yaitu GCG, CSR, intellectual capital dan kinerja keuangan sedangkan sisanya sebesar $24,5 \%$ nilai perusahaan dijelaskan oleh variabel atau sebab-sebab lainnya diluar model.

\section{Uji Hipotesis}

Untuk mengetahui nilai $\mathrm{t}$ statistik tabel ditentukan tingkat signifikansi $5 \%$ dengan derajat kebebasan yaitu $\mathrm{df}=(\mathrm{n}-\mathrm{k}-1)$, dimana $\mathrm{n}=$ jumlah observasi dan $\mathrm{k}=$ jumlah variabel. Pada penelitian ini jumlah observasi sebanyak 45 dan jumlah variabel sebanyak 4 sehingga nilai $\mathrm{df}=40(45-4-1)$. Berdasarkan nilai df 40 maka didapatkan 
nilai $\mathrm{t}$ tabel sebesar 1,683 atau -1,683. Uji parsial masing-masing variabel dapat dijelaskan sebagai berikut:

\section{Pengaruh GCG Terhadap Nilai Perusahaan}

Berdasarkan hasil olah data menunjukkan $t$ hitung GCG sebesar 2,128 dan $t$ tabel sebesar 1,683 sehingga thitung lebih besar dari t tabel $(2,128>1,683)$ artinya terdapat pengaruh positif GCG terhadap nilai perusahaan. Nilai signifikasi sebesar 0,040 lebih kecil dari 0,05 $(0,040<0,05)$ artinya signifikan, dapat disimpulkan bahwa terdapat pengaruh positif signifikan GCG terhadap nilai perusahaan

\section{Pengaruh CSR Terhadap Nilai Perusahaan}

Berdasarkan hasil olah data menunjukkan $t$ hitung CSR sebesar 10,164 dan $t$ tabel sebesar 1,683 sehingga thitung lebih besar dari t tabel $(10,164>1,683)$ artinya terdapat pengaruh positif CSR terhadap nilai perusahaan. Nilai signifikasi sebesar 0,000 lebih kecil dari 0,05 $(0,000<0,05)$ artinya signifikan, dapat disimpulkan bahwa terdapat pengaruh positif signifikan CSR terhadap nilai perusahaan

\section{Pengaruh Intellectual Capital Terhadap Nilai Perusahaan}

Berdasarkan hasil olah data menunjukkan $t$ hitung intellectual capital sebesar $-0,249$ dan $t$ tabel sebesar $-1,683$ sehingga $t$ hitung lebih kecil dari $t$ tabel $(-0,249<1,683)$ artinya tidak terdapat pengaruh negatif intellectual capital terhadap nilai perusahaan. Nilai signifikasi sebesar 0,805 lebih besar dari 0,05 $(0,805>0,05)$ artinya tidak signifikan, dapat disimpulkan bahwa tidak terdapat pengaruh intellectual capital terhadap nilai perusahaan.

\section{Pengaruh Kinerja Keuangan Terhadap Nilai Perusahaan}

Berdasarkan hasil olah data menunjukkan thitung kinerja keuangan sebesar 3,704 dan $\mathrm{t}$ tabel sebesar 1,683 sehingga $\mathrm{t}$ hitung lebih besar dari $\mathrm{t}$ tabel $(3,704>1,683)$ artinya terdapat pengaruh positif kinerja keuangan terhadap nilai perusahaan. Nilai signifikasi sebesar 0,001 lebih kecil dari 0,05 $(0,001<0,05)$ artinya signifikan, dapat disimpulkan bahwa terdapat pengaruh positif signifikan kinerja keuangan terhadap nilai perusahaan.

\section{PEMBAHASAN}

\section{Pengaruh GCG Terhadap Nilai Perusahaan}

Hasil penelitian menunjukkan bahwa terdapat pengaruh positif signifikan GCG terhadap nilai perusahaan artinya semakin tinggi GCG yang di ukur dengan komite audit maka semakin tinggi nilai perusahaan, begitu pula sebaliknya semakin rendah GCG maka semakin rendah nilai perusahaan, dalam penelitian ini menunjukkan bahwa jumlah komite audit perusahaan sektor farmasi yang terdaftar di Bursa Efek 
Indonesia cukup banyak sehingga nilai perusahaan tinggi. Hal ini menunjukka bahwa komite audit yang dibentuk oleh dewan komisaris dapat melaksanakan kinerjanya dalam melakukan pengawasan terhadap tata kelola perusahaan. Komite audit perusahaan sektor farmasi yang berjumlah paling sedikit 3 orang dapat mengawasi kinerja manajemen khususnya dalam laporan keuangan hal ini dapat menunjukkan bahwa transparasi pertanggungjawaban manajemen dapat dipercaya sehingga tingkat kepercayaan investor terhadap perusahaansektor farmasi semakin meningkat hal ini tentu dapat pula meningkatkan nilai perusahaan.

Hasil ini didukung oleh penelitian yang dilakukan oleh Susanti et al. (2010) yang menjelaskan bahwa komite audit mempunyai peran penting dalam memelihara proses laporan keuangan yang akurat dengan melaksanakan GCG dan menjaga stsiem pengawasan perusahaan.

\section{Pengaruh CSR Terhadap Nilai Perusahaan}

Hasil penelitian menunjukkan bahwa terdapat pengaruh positif signifikan CSR terhadap nilai perusahaan artinya semakin tinggi CSR yang diungkapkan oleh perusahaan maka semakin tinggi nilai perusahaan, begitu pula sebaliknya semakin rendah CSR yang diungkapkan oleh perushaan maka semakin rendah nilai perusahaan, dalam penelitian ini menunjukkan bahwa banyak indikator CSR yang diungkapkan oleh perusahaan sektor farmasi yang terdaftar di Bursa Efek Indonesia cukup banyak sehingga nilai perusahaan tinggi.

Menurut penelitian yang dilakukan oleh Adnantara (2013) yang menemukan bahwa CSR berpengaruh positif signifikan pada Nilai Perusahaan. Hal ini mengindikasikan bahwa dengan adanya pengungkapan CSR oleh perusahaan, maka investor akan memberikan respon yang positif sehingga banyak investor yang berinvestasi pada perusahaan tersebut. Temuan ini mendukung penelitian yang dilakukan oleh Harjoto dan Jo (2011) serta Hackson dan Milne (1996).

\section{Pengaruh Intellectual Capital Terhadap Nilai Perusahaan}

Hasil penelitian menunjukkan bahwa tidak terdapat pengaruh intellectual capital terhadap nilai perusahaan artinya naik turunnya kekayaan intellectual yang dimiliki oleh perusahaan tidak mempengaruhi nilai perusahaan. Hal ini menunjukkan bahwa intellectual capital kurang menjadai bahan pertimbangan investor dalam mengukur kinerja perusahaan, investor lebih mempertimbangkan faktor lain dalam melakukan investasi pada perusahaan seperti harga saham atau kinerja keuangan.

Hasil penelitian ini didukung oleh penelitian yang dilakukan oleh Kuryanto dan Muchamad (2008), Yuniasih dkk. (2010); Solikhah (2010); Sunarsih dan Mendra (2012); Faza dan Hidayah (2014) yang menjelaskan bahwa modal intelektual tidak berpengaruh pada nilai pasar perusahaan, hal ini terjadi karena kemungkinan banyak Negara berkembang khususnya Indonesia yang belum memperhatikan modal intellectual capital sebab dianggap baru hangat menjadi bahan perbincangan di forum 
Internasional. Perusahaan belum dapat mengelola informasi mengenai intellectual capital dengan baik dan benar untuk dijadikan pedoman kinerja perusahaan sebagai bahan pengambilan keputusan.

\section{Pengaruh Kinerja Keuangan Terhadap Nilai Perusahaan}

Hasil penelitian menunjukkan bahwa terdapat pengaruh positif signifikan kinerja keuangan terhadap nilai perusahaan artinya semakin tinggi kinerja keuangan yang di ukur dengan ROA maka semakin tinggi nilai perusahaan, begitu pula sebaliknya semakin rendah kinerja keuangan maka semakin rendah nilai perusahaan, dalam penelitian ini menunjukkan bahwa ROA perusahaan sektor farmasi yang terdaftar di Bursa Efek Indonesia cukup banyak sehingga nilai perusahaan tinggi. Hal ini menunjukkan bahwa perusahaan sektor farmasi menunjukkan kinerja yang sangat baik dalam mengelola asset perusahaan sehingga dapat menghasilkan keuntungan yang tinggi bagi perusahaan. Perusahaan sektor farmasi menunjukkan bahwa perusahaan dapat mengelola dana internalnya dengan baik sehingga menghasilkan keungtungan yang tinggi sehingga investor akan tertarik untuk menanamkan saham pada perusahaan hal ini tentu dapat meningkatkan nilai perusahaan.

Hasil penelitian ini didukung oleh penelitian yang dilakukan oleh Novari dan Lestari (2016); Suranto, dkk (2017) yang menjelaskan bahwa profitabilitas yang diukur dengan ROA berpengaruh terhadap nilai perusahaan, hal ini menunjukkan bahwa profitabilitas yang tinggi dapat meningkatkan respon positif investor untuk meningkatkan harga saham sehingga nilai perusahaan juga akan meningkat

Menurut Novari dan Lestari (2016) profitabilitas memiliki pengaruh yang positif dan signifikan terhadap nilai perusahaan. Hal ini berarti Profitabilitas yang tinggi menunjukkan prospek perusahaan yang bagus sehinggga memicu permintaan saham oleh investor. Respon positif dari investor tersebut akan meningkatkan harga saham dan selanjutnya akan meningkatkan nilai perusahaan.

\section{KESIMPULAN}

Berdasarkan hasil penelitian menjelaskan bahwa terdapat pengaruh positif signifikan GCG terhadap nilai perusahaan, terdapat pengaruh positif signifikan CSR terhadap nilai perusahaan, tidak terdapat pengaruh intellectual capital terhadap nilai perusahaan serta terdapat pengaruh positif signifikan kinerja keuangan terhadap nilai perusahaan

\section{UCAPAN TERIMA KASIH}

Ucapan terima kasih penulis sampaikan kepada segenap teman dan keluarga yang membantu dalam menyelesaikan artikel ini, serta terima kasih kepada reviewer yang telah memberikan kritik dan saran sehingga artikel ini dapat terselesaikan. 


\section{DAFTAR PUSTAKA}

Adnantara, Komang Fridagustina. "Pengaruh struktur kepemilikan saham dan corporate social responsibility pada nilai perusahaan." Buletin studi ekonomi (2014): 44232.

Amr. 2016. Omzet Perusahaan Farmasi Menurun Demi Masyarakat. Diunggah Selasa, $192016 \quad$ Januari $\quad 2016 \quad 10: 59 \quad$ wib http://economy.okezone.com/read/2016/01/19/320/1291593/omzet-perusahaanfarmasi-menurun-demi-masyarakat

Anam, O. A., Fatima, A. H., \& Majdi, A. R. H. (2011). Effects of Intellectual Capital Information Disclosed in Annual Reports on Market Capitalization Evidence From Bursa Malaysia. Journal of Human Resource Costing \& Accounting, Emerald, 15(2), 85-101. https://doi.org/10.1108/14013381111157328

Belkaoui, Ahmed Riahi. (2003). Intellectual Capital and Firm Performance of US Multinational Firms: a Study of The Resource-Based and Stakeholder Views. Journal of Intellectual Capital. Vol. 4 No. 2. pp. 215-226.

Berzkalne, I., \& Zelgalve, E. (2014). Intellectual Capital and Company Value. Procedia - Social and Behavioral Sciences, 110, 887-896. https://doi.org/10.1016/j.sbspro.2013.12.934

Bontis, N. (1998). Intellectual capital: an exploratory study that develops measures and models. Management Decision, Vol. 36 No. 2, pp. 63-76.

Brigham, Eugene F. dan Louis C. Gapenski. (1996). Intermediate Financial Management. Fifth Edition. New York: The Dryden Press

Cadbury Commite of United Kingdom. (1922). "Corporate Governance”. Inggris

Chariri, Anis. (2008). Kritik Sosial atas Pemakaian Teori dalam Penelitian Pengungkapan Sosial dan Lingkungan. Jurnal Maksi, 8(2), h: 151-169.

Chen, M.C., S.J. Cheng, Y. Hwang. (2005). “An Empirical Investigation of the Relationship Between Intellectual Capital and firms' Market Value and Financial Performances". Journal of Intellectual Capital Vol. 6 No. 2.pp. 159-176.

Cheng, Megawati dan Yulius Logi Christiawan. (2011). Pengaruh Pengungkapan Corporate Social Responsibility terhadap Abnormal Return. Jurnal Akuntansi dan Keuangan, 13(3), Mei 2011, h: 24-36

Endiana, I. Dewa Made . (2019). "Implementasi Corporate Governance Pada Corporate Social Responsibility Terhadap Nilai Perusahaan." Jurnal Riset Akuntansi (JUARA) 9.1 (2019): 92-100.

Faza, Muhammad Fardin, and Erna Hidayah. (2015) "Pengaruh intellectual capital terhadap profitabilitas, produktivitas, dan nilai perusahaan pada perusahaan perbankan yang terdaftar di Bursa Efek Indonesia (BEI)." Ekbisi 8.2 (2015).

Firer, S., dan S. M. Williams (2003). Intellectual Capital and Traditional Measures Of Corporate Performance, Journal Of Intellectual Capital, Vol.4, No.3. 
Ghoul, Sadok El, Omrane Guedhami, Chuck C. Y. Kwok and Dev R. Mishra. (2011). Does Corporate Social Responsibility affect the cost of capital?. Journal of Banking \& Finance, 35 (9), pp: 2388-2406.

Hackson, David dan Milne, Marcus J. (1996). Some Determinants of Social and Environmental Disclosures in New Zaeland Companies, Accounting, Auditing and Accountability Journal. Vol 9: Hal. 77- 108

Harjoto, Maretno A. and Hoje Jo. (2011). Corporate Governance and Firm Value: The Impact of Corporate Social Responsibility. Journal of Business Ethics, 2011.

Heinkel, Robert, Alan Kraus., dan Josef, Zechner. (2001). The effect of green investment on corporate behavior. Journal of Financial and Quantitative Analysis, 36(4),pp:431.

Husnan, Suad. (1996). Manajemen Keuangan. Yogyakarta : BPFE - Yogyakarta.

Kuryanto, Benny \& Muchamad Syafrudin. (2008). Pengaruh Modal Intelektual Terhadap Kinerja Perusahaan. Makalah Disampaikan dalam Simposium Nasional Akuntansi XI. Pontianak: 23-24 Juli.

Miller, M. H \& Modigliani, F. (1961). Dividend Policy under Asymetric Information. Journal of Finance. 411-433

Mohsen, Iranhamid., Moeinaddin, Mahmoud, Shahmoradi., Nasim, Shahmoradi, dan Heyrani,Forough. (2014). The Effect of Intellectual Capital on Cost of Finance and Firm Value. International Journal of Academic Research in Acounting, Finance, and Management Sciences, Vol.4, N0. 2:1-8.

Nofrita, Ria. (2013). Pengaruh Profitabilitas terhadap Nilai Perusahaan dengan Kebijakan Dividen sebagai Cariabel Intervening (studi empiris pada perusahaan manufaktur yang terdaftar di BEI). Jurnal Fakultas Ekonomi Universitas Negeri Padang.

Novari, Putu Mikhy, and Putu Vivi Lestari. (2016) "Pengaruh ukuran perusahaan, leverage, dan profitabilitas terhadap nilai perusahaan pada sektor properti dan real estate." E-Jurnal Manajemen Universitas Udayana 5.9 (2016).

Orens, R., Aerts, W., \& Lybaert, N. (2009). Intellectual Capital Disclosure , Cost of Finance and Firm Value. Journal of Human Resource Costing \& Accounting

Pulic, A. (2000). Intellectual Capital: Navigating the New Business Landscape. Macmillan Press Ltd. London

Randa, F., \& Solon, S. A. (2012). Pengaruh modal intelektual terhadap nilai perusahaan. Jurnal sistem informasi manajemen dan akuntansi , 24-47

Rivandi, Muhammad. (2018). "Pengaruh intellectual capital disclosure, kinerja keuangan, dan kepemilikan manajerial terhadap nilai perusahaan." Jurnal Pundi 2.1 (2018).

Rizqia, Dwita Ayu, Siti Aisjah dan Sumiati. 2013. Effect of Managerial Ownership, Financial Leverage, Profitability, Firm Size, and Investment Opportunity on Dividend Policy and Firm Value. Research Journal of Finance and Accounting, Vol 4 (11):Hal.120-130. 
Rustiarini, Ni Wayan. (2010). "Pengaruh Corporate Governance Pada Hubungan Corporate Social Responsibility dan Nilai Perusahanan". Simposium Nasional Akuntansi XIII. AKPM_12.

Salvatore, Dominick. (2005). Ekonomi Manajerial Dalam Perekonomian Global. Jakarta : Salemba Empat.

Sawarjuwono, Tjiptohadi dan Agustine Prihatin Kadir. (2003). Intellectual Capital: Perlakuan, Pengukuran dan Pelaporan (Sebuah Library Research). Jurnal Akuntansi dan Keuangan. Vol 5, No. 1, 31- 51.

Siallagan, Hamonangan dan Machfoedz, Mas'ud. 2006. "Mekanisme Corporate Governance, Kualitas Laba dan Nilai Perusahaan". Simposium Nasional Akuntansi 9. Padang, 23-26 Agustus.

Solikhah, Badingatus, Abdul Rohman,Wahyu Meiranto. (2010). Implikasi Intellectual Capital terhadap Financial Performance, Growth dan Market Value; Studi Empiris dengan Pendekatan Simplisitic Specification. Makalah Disampaikan dalam Simposium Nasional Akuntansi XIII. Purwokerto: 13-15 Oktober.

Stewart, T A. (1997). Intellectual Capital: The New Wealth of Organizations. New York: Doubleday.

Sunarsih, N.M dan Ni Putu Yuria Mendra. (2012). Pengaruh Modal Intelektual Terhadap Nilai Perusahaan Dengan Kinerja Keuangan Sebagai Variabel Intervening Pada Perusahaan Yang Terdaftar Di Bursa Efek Indonesia. Makalah Disampaikan dalam Simposium Nasional Akuntansi XV. Banjarmasin: 20-23 September.

Suranto, Vintia AH M., and Stanley K. Walandouw. (2017)."Analisis Pengaruh Struktur Modal dan Kinerja Keuangan Terhadap Nilai Perusahaan Pada Perusahaan Perbankan di Bursa Efek Indonesia." Jurnal EMBA: Jurnal Riset Ekonomi, Manajemen, Bisnis dan Akuntansi 5.2 (2017).

Susanti, Angraheni Niken, Rahmawati dan Aryani, Y Anni. 2010. “Analisis Pengaruh Mekanisme Corporate Governance Terhadap Nilai Perusahaan Dengan Kualitas Laba Sebagai Variabel Intervening Pada Perusahaan Manufaktur Yang Terdaftar Di Bursa Efek Indonesia Periode 2004-2007". Simposium Nasional Keuangan I

Tan, H.P., D. Plowman, P.Hancock. (2007). "Intellectual capital and financial returns of companies". Journal of Intellectual Capital. Vol. 8 No. 1. pp. 76-95.

Widianingsih, Dewi. (2018). "Kepemilikan Manajerial, Kepemilikan Institusional, Komisaris Independen, Serta Komite Audit Pada Nilai Perusahaan Dengan Pengungkapan CSR sebagai Variabel Moderating dan Firm Size sebagai Variabel Kontrol." Jurnal akuntansi dan Pajak 19.1 (2018): 38-52.

Yunita, Novelina. (2012). "Pengaruh Modal Intelektual Terhadap Kinerja Keuangan Dan Nilai Pasar". Accounting Analysis Journal 1 (1). 